\title{
The method of situational factors analysis about problems and its teaching essentials
}

\section{Xu Bo}

\begin{abstract}
The problem and the situation have close relationships, complex situational factors and their interaction relationships contain the solutions to the problems. Through the steps of defining the problems, defining the problem situations, analyzing internal and external situational factors and their interaction relationships of the problems, examining and distinguishing the factors and their relationships and so on, the method aims at helping students to understand and characterize the problems better, and then to seek solutions to problems by the clue to the situational factors of the problem. When using this method, teachers should pay attention to the combination of theoretical explanations and practical analyses, considering the characteristics of the students' thinking stage fully, and using other methods of problem analysis meantime.
\end{abstract}

Key words: problem, situational factor, thinking method. 


\title{
Metoda analýzy situačních faktorů o problémech a jeho učebních potřebách
}

\begin{abstract}
Abstrakt
Existuje blízký vztah problému a situace, komplex situačních faktorů a jejich vzájemné vztahy obsahují řešení problémů. Prostřednictvím definice problémů, problémových situací, analýzy interních a externích situačních faktorů a jejich interakčních vztahů, zkoumání a rozlišování faktorů a jejich vztahů je cílem této metody pomoci studentům porozumět a charakterizovat problémy lépe a poté hledat řešení problémů pomocí klíčových slov k situačním faktorům problému. Při použití této metody by učitelé měli věnovat pozornost kombinaci teoretických vysvětlení a praktických analýz, přičemž plně zohledňují charakteristiky studentského myšlení a využívají jiné metody analýzy problémů.
\end{abstract}

Klíčová slova: problém, situační faktor, metoda myšlení.

\section{Introduction}

The method is one of the key factors to solve any problem. From different dimensions, the methods can be divided into different types. According to the universal, abstract degree, the methods can be divided into three layers: specific methods, thinking methods and philosophical methods. For solving the specific problems, it's difficult to take the Philosophical methods as the action strategies, because they are often more macro, vague. Yet the concrete methods are too meticulous, often apply to specific domains and situations. The thinking methods belong to the middle levels, they are comprehensive, but also practical. Therefore, they are very important for problem solving, We should pay more attention to them.

The cultivation of thinking abilities, training of thinking method is an important content in education and teaching. The students can only apply the knowledge and skills that have been learned to the practical life and transformations of external world unless they master the right way of thinking, form the habits and abilities of thinking independently, analyzing and solving problems (Qian Xuesen, 1986). In the processes of teaching, there are many ways to cultivate students' thinking abilities. Combined with a large number of educational practices, author finds that it's an effective way through guiding the students to analyze the internal and external situational factors directly or indirectly related to the problem and their interaction relationships, then seeking solutions to problems. 


\section{The concepts of "problem", "situation", and "problem situation"}

General speaking, the "Problem" is the contradiction or difficulty that needs to be studied, discussed and solved. In the field of psychology, it's often understood as an individual psychological dilemma guided by some purpose when someone intends to do something, but hasn't found the proper means (Zhang Chunxing, 1998). According to different nature, problems can be divided into several types, but all of them contain three elements: known conditions, the known environment, objects or other information of the problem; objectives, the ultimate ideal state of problem solving; barriers, many difficulties that the individual needs to overcome in the process of reaching the target state by using known conditions (Shi Baoguo Shen Jiliang, Xu Jingjing, 2005).

"Situation" means some cesnes or circumstances. It contains the meaning of abstract prospect besides specific circumstances, scenes. From the point of view of problem solving, situation can be understood as the environment or background for individuals to solve problems. It is a series of stimulus events or information materials that makes the individual produce some emotional experience then induce individual analysis, solve the problem. And it is also the carrier of information transmissions (Pan Lixia, 2007). From this point of view, situational factors that affect the problem solving include both internal and external factors of the problem, as well as the external factors and their interactions which are directly or indirectly related to the problem solving. Machu J Kim, a famous psychologist, defines the "problem situation" as a form of psychological interaction between the subject and object, Its primary feature is that a psychological state of the subject when acquiring new knowledge, skills, and solving new problems (Ding Nianjin, 2005).

\subsection{The relationship between "problem" and "situation", and its enlightenment of "problem solving"}

At present, researchers generally believe that "problem" and "situation" have a close relationship. For example, some scholars point out that the problem is a situation, the difficulty of the problem depends on the complexity of the situation, the situation is more complex, the problem more difficult (Zhang Dajun, 2004). In fact, any problem always arises in a specific situation, rather than independent existence without a basis. The problem itself contains a wealth of situational factors, at the same time, it is also restricted by external situational factors, the problem and the corresponding situational factors are inextricably linked. Therefore, the so-called "problem solving" process can often be translated into the following steps: analyzing all the sub situational factors and their interaction relationship belong to the problem itself; clarifying the external 
situational factors and their interaction directly or indirectly related to the problem; clarifying the interaction relationship between external or internal situational factors of the problem. In other words, the complex situational factors and their interaction relationships external or internal the problem contain the answer to the problem.

\subsection{The appropriateness of "situational factor analysis" to "problem solving"}

There are many models for problem solving. The typical model includes some steps: understanding the problem, finding a answer, trying to solve, evaluating and so on. It's first step is to understand and characterize the problem, that to say the accurate description of the problem, in order to achieve the purpose of understanding the background of the problem and understanding the existing conditions of the problem solver. The problem solving process in a typical mode can be represented by the following schematic diagram(Chen Qi, Liu Rude, 2007).

\section{Figure 1}

A pattern of problem solving process

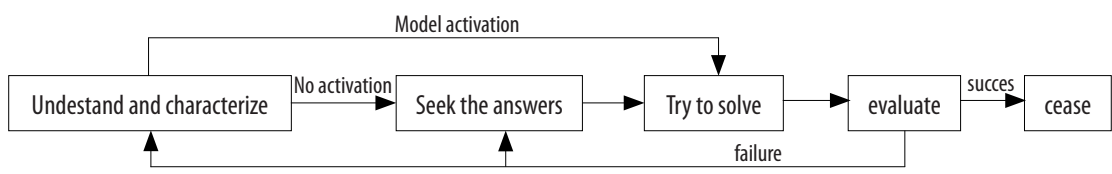

According to the figure 1 above, "Understanding and characterizing" is the first step for this mode. In fact, regardless of any mode, an accurate description of the problem and understanding the problem itself is the primary key to solve the problem. There are many specific methods for understanding and characterizing problems based on different theories. The author suggests it's an easy important way for students to understand and master starting from the relationship between problem and situation, characterizing the problem, then to solve the problem, according to the analysis of relationship between "problem" and "situation" and it's enlightenment for "problem solving" above, and combined with a large number of educational practices.

In the process of problem solving, the students' cognition and emotion are interactive, emotion will regulate, strengthen, and power the cognitive activities. Situational analysis and thinking help to stimulate students' good emotional experience, then to enhance the effect of emotion on cognitive activities; the process of problem solving is also the process of interaction between intuitive and abstract thinking; situational analysis is helpful to make abstract thinking concrete, promote the integration of in- 
tuitive and abstract thinking, and help students from intuitive perception to abstract, rational insight. Besides through the analysis of situational factors and their interaction relationship directly or indirectly related to the problem, it is also beneficial for students to be conscious of unconscious mental activities, then to enhance the consciousness and initiative of the thinking. Therefore, "situational factor analysis" has strong relevance to "problem solving", It helps students more actively, clearly and quickly seek clues to analyze and solve problems.

\section{The teaching steps of the method of "situational factors analysis"}

In order to help students better understand the problem, analyze the relationship between problem and situation, then to find a solution to the problem, we can translate the related concept about analysis of specific situational factors into the operated thinking process and strategy from the view of point of actual teaching. On the basic of a lot of teaching experience, the author conclude the following teaching steps gradually.

\subsection{Identifying the problem}

Identifying problem is the first step in solving problems. If the problem requires students to put forward, teachers should guide them to mind the difficulties or doubts that "only to be sensed, but not explained", and make them conscious, worded, clearly define the connotation and extension of the problem, analyze its difficulty, and use accurate words to generalize the problem refinedly; If the problem to be solved is clear, it also should make students know the elements of the problem, for example, the nature, the scope, the known conditions, the target state and the main obstacles of the problem.

In the initial stage of problem solving, it's hard for the students to define the problem clearly and accurately if the problem is difficult or unfamiliar for them. Therefore, it can help students understand and define problems better by means of situational display, practical operation, problem situation reappearance and process or paper writing thinking.

\subsection{Defining the situation of the problem}

Although the stage of "identifying the problem" has been involved in understanding and analysis of problem situations, it is necessary to define the problem situation clearly in order to analyze the relationship between the problem and the situation deeply, and effectively seek solutions to the problem. According to different criteria, "problem situ- 
ation" can be classified into different categories. For example, according to the different degrees of abstraction it can be divided into specific situations, abstract situation; according to the scope, it can be divided into macro situation, meso situation and micro situation; according to the characteristics of time and space, time and space can be divided into situational context; according to the saliency, it can be divided into explicit situation and implicit situation and so on.

When using the method of situational factors analysis, clearly defining the problems occurring in the actual operation situation, mainly means identifying the context or background of the problem from the "internal-external" dimension and other dimensions. If the problem is simple, or students are familiar with it, the problem situation can be analyzed directly; if the problem is difficult or students are unfamiliar with it, it can be combined with the specific experience of students' study, life or practice, looking for special cases related to this problem, or similar but more familiar issues as inspiration. Through the analysis of their familiar even personal experience of special cases and problems, help them to achieve the purpose of understanding and analysis of the target problem situations. That's to say, making the abstract situation concrete, making the unfamiliar situation familiar, making the fragmented situation correlative.

\subsection{Analyzing the internal, external situation factors and their relationships of the problem}

In order to seek a solution to the problem better, students should be guided to analyze the situational factors in detail from the defined problem situations: analyze the situational sub factors and their relationships of the problem itself; analyze the external situational sub factors and their relationships directly or indirectly related to the problem; analyze the relationships between internal and external situational factors of the problem.

In the analysis, we should adhere to the principle of refining and deepening from macro to micro, step by step. Firstly, analyze the main situational factors which are directly or indirectly related to the problem, then analyze the secondary situational factors corresponding to each of the main factor, the steps cease until presenting the specific sub factors of the major factors related to problem solving.

In the operation, we should first analyze the situational factors of the problem, and then analyze the relationship between the different factors. In addition to analyzing the relevant factors and interaction relations of the problem horizontally, we should use the method of longitudinal analysis, and search for the situational factors related to problem solving. Through the analysis above, we can get a network about the problem related contextual factor composed of different levels of factors and their relationships. The network can be presented by the form of a tree diagram visually. 


\subsection{Judging and discriminating the situational factors and their interactional relationships}

In the stage of analyzing different levels of sub situational factors related to the problem, brainstorming is the most important method, it's necessary to list the relevant sub situational factors at all levels as comprehensive, accurately as possible from the specific context dimension. However, whether the result of the analysis is comprehensive, reasonable, and whether it is beneficial to seek solutions to the problem requires further judgment and discrimination.

All of the missing important situational sub factors should be added to the corresponding levels of situation factors network of the problem; repeated or not high degree of sub factors associated with the problem should be deleted; if the relationship between the same level or different levels is contrary to the basic dimension of analysis or logical confusion, it should be adjusted and optimized.

In addition, it's necessary to carefully discriminate the appropriateness of the analysis about situational factors between internal and external or different levels. If not proper, it should be corrected. Through these optimizations, judgment and discrimination, We can get a network diagram of all levels sub situational factors and their relationship related to high degree of correlation with the problem.

\subsection{Seeking the solution with the clue of the situational sub factors of the problem}

The process of problem solving itself contains motivations, contents, methods, environments and other factors. They are relatively independent and connected with each other and reflected in the analysis of the steps above. It's always inextricably linked with these factors and their relationship to solve the problem scientifically and effectively. Therefore in the process of seeking the solution, it is necessary to refine and divide the attention into the content of the problem, that is, the analysis of the sub factors of the problem situation. Then to conclude gradually and form solutions to the problem through specific arrangements, combinations, operations, or thorough analysis about the sub situational factors and their relationship of the problem. That is to say, the solution to the problem is contained in the complicated situation factors and their interaction within the problem.

The contents above are the five steps of situational factor analysis that are relatively independent. In the practical application process, these steps are interrelated, enlightening and merging with each other. Analysis and thinking about the previous step scientifically, effectively and reasonably contains the attention and understanding of the latter step, it's the premise and basis to ensure the smooth progress of the latter steps; in the process of analysis and discussion about a latter step, the understanding 
of the previous step can also be further improved and deepened; in the process of real analysis and thinking, these steps are often blended together.

In addition, whether the "solution" formed by the five steps above is feasible or not, it still needs to be tested by practice. That means guiding practice with established strategies, optimizing and improving the solution to the problem in practice, continuously promoting the common growth and progress of both teachers and students.

\section{A teaching example for the method of situational factor analysis}

In order to illustrate the application steps of the method of "situational factors analysis", the author takes the example of "how to deal with children's problematic behaviors in collective teaching background".

The first step is to define the problem: in this example, the key issue is "how to deal with children's problematic behaviors". Its essence is to seek methods of intervention for the children's problematic behaviors from multiple dimensions under the special space-time background of "collective teaching".

The second step is to define the situation of the problem: in this problem, although clearly presented the situation "collective teaching", it is not pointed out what kind of specific situation the collective teaching is, what's the kind of the children, what's the kind of specific problem behavior, and what's the type of teachers and so on. So the problem situation corresponding to this problem is a general, collective teaching situation that causes children to have problematic behaviors.

The third step is to analyze the internal and external situational factors and their relationships of the problem: in this example, the widespread situations of children's problematic behaviors involve teachers, children themselves, peers, teaching activities, external teaching environments and other macro situational factors. Each macro factor includes several sub situational factors. Take the factor "teacher" influencing children's problematic behaviors as an example, its sub situational factors include "concept towards students", "teaching attitude", "teaching language", "teaching organizing ability", "charisma", "teaching experience", "ability of thinking" and so on. After the similar multilevel analysis and decomposition to each macro factor, a diagram of situational different levels sub factors related to children's problematic behaviors can be initially obtained. The specific contents are as shown in the following figure: 
Figure 2

Situational sub factors analysis about children's problematic behaviors

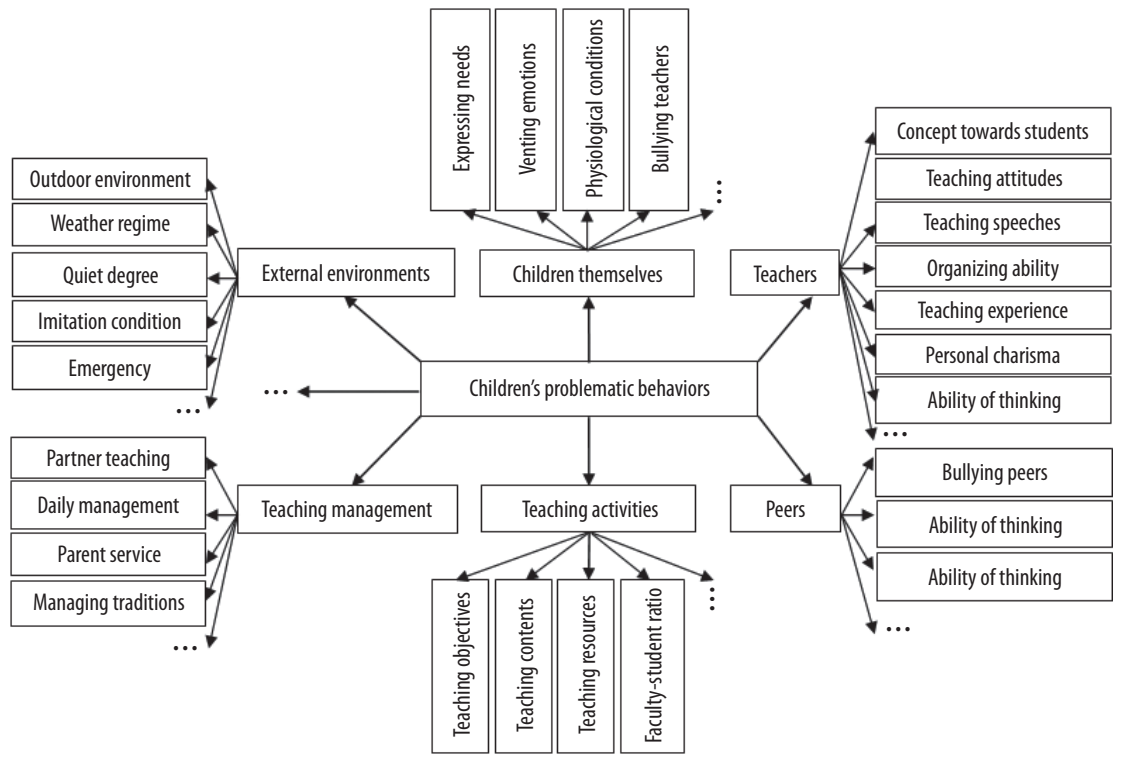

The figure above shows the multiple situational factors associated with children's problem behavior in general, the sub factors of internal factors, and between all levels have a direct or indirect association. The relationships between these situational sub factors restrict each other, their combined force affect the solving of the core problem.

The fourth step is to judge and identify the situational factors and their relationship: as for the analyzed all levels of situational sub factors and their relationships, they should be further optimized and discriminated, the ones that highly correlated with the problem will be reserved, perfect, related and straightened out the relationship between them. Such as dividing one of the primary situational factors "teaching activities" influencing children's problematic behaviors into several categories: "faculty-student ratio", "teaching resources", "teaching contents", "teaching objectives" and so on. Each main situational factor can be further divided into two or three lower level factors.

The fifth step is to find the solution to the problem by taking the situational sub factors of the problem as clues: after the last step of judgment, screening, optimization, the multi-level clues to solve the problem are found. So far, combined with the specific case of teaching and education in the real scene, the problem of "how to deal with the problematic behavior of individual children" is transformed into the following strategies: 
"improving teachers' view of students", "richening teaching resources", "establishing partner aid system", "creating a quiet learning environment", "improving children's ability to express" and so on. Then to verify their effectiveness in actual teaching.

\section{The notices in the use of the method of situational factors analysis}

When using this method, teachers should not only explain the theory to students, but also need to help them master the use of the method of each link and the main points combined specific problems and through a lot of practical analysis. At the same time, they must consider the characteristics of students' physical and mental development. For example, if the students are still in the image and intuitive thinking stage, the specific and image teaching should be paid more attention to in each link and each process. Teachers often need to resort to more material objects, models, pictures, or specific words in the process of teaching and analysis; The method of situational factor analysis itself is not complicated, if the teacher explain the core ideas and implementation methods of each operational step to the students, they can quickly understand this method theoretically. However, if the students to be trained to use this method of consciously and initiatively, even form a habit of this thinking, the teachers should set a good example and give them long-term edification in the normal learning and life. In addition, problems including various types, and there are more than one way to understand and characterize problems. It's hard to solve the factual problems by the method of situational analysis such as "what are the educational thoughts of Confucius?", "what day is today?". Therefore, in the real situation of solving problems, this method is often used in conjunction with other methods, in order to understand and analyze efficiently, then solve the problem finally.

The cultivation of thinking ability is one of the eternal topics of education. Thinking skills, like motor skills, can be acquired through training. Thinking training can effectively helps students to master the skills and abilities of thinking in a certain range and under certain conditions (Wang Xiaoyan, 2004). It is an important duty for teachers to continuously improve students' thinking quality, to help them gradually optimize and perfect their own thinking system. As long as using this method skillfully and frequently, teachers can help improve the students' ability of understanding, analysis and problem solving. 


\section{References}

Qian Xuesen, (1986). About the science of thinking. Shanghai: Shanghai people's publishing house, 23.

Zhang Chunxing, (1998). Educational psychology. Hangzhou: Zhejiang education press.

Shi Baoguo, Shen Jiliang, Xu Jingjing, (2005). On the "problems" in problem based learning. Shanghai research on education, (7).

Pan Lixia, (2007). Research on the creation of problem situation in junior high school mathematics classroom. Nanjing: Nanjing Normal University.

Ding Nianjin, (2005). Problem teaching. Fuzhou: Fujian education press.

Zhang Dajun, (2004). Educational psychology. Beijing: People's education press.

Chen Qi, Liu Rude, (2007). Contemporary educational psychology. Beijing: Beijing Normal University press.

Wang Xiaoyan, (2004). Scientific thinking and scientific methodology. Guangzhou: South China University of Technology press.

\section{Contact:}

Xu Bo

Faculty of Special Education, Leshan Normal University

Binhe road 778, Shizhong district, Leshan city, Sichuan province, China

E-mail: xianqingxuzhang@qq.com

Mgr. Xu Bo is a full-time teacher in faculty of special education of Leshan Normal University. He has long been engaged in teaching and scientific research on basic theory of special education curriculum and teaching, teachers education in special education, critical thinking and so on. 